\title{
Hubungan Kadar Seng dan vitamin A dengan Kejadian ISPA dan Diare pada Anak
}

\author{
Fedriyansyah, ${ }^{*}$ HM Nazir Hz, ${ }^{*}$ Theodorus, ${ }^{* *}$ Syarif Husin ${ }^{* * *}$ \\ *Departemen Ilmu Kesehatan Anak, ${ }^{* *}$ Bagian Farmakologi**Bagian Gizi. Fakultas Kedokteran Universitas \\ Sriwijaya/RSMH Palembang
}

\begin{abstract}
Latar belakang. Rendahnya sistem imunitas dianggap turut berpengaruh terhadap kejadian ISPA dan diare. Beberapa penelitan menyatakan bahwa kadar seng dan vitamin A dalam serum yang rendah juga berpengaruh terhadap sistim imun.

Tujuan.Untuk mengetahui hubungan antara status seng dan vitamin A dengan kejadian ISPA dan diare pada anak.

Metode. Penelitian kohort selama enam bulan di lima posyandu di wilayah kerja Puskesmas Talang Ratu, Palembang. Subjek penelitian adalah anak berumur 12-60 bulan yang datang ke Posyandu pada bulan Februari 2009. Kadar seng dan vitamin A diperiksa, serta mendapat vitamin A sesuai program pemerintah. Data ISPA dan diare dari subjek, dikumpulkan selama 6 bulan dan selanjutnya dianalisis dengan program SPSS 15.

Hasil. Terdapat 100 subjek ikut dalam penelitian, namun 8 subjek tidak melanjutkan, sehingga terdapat 92 subjek. Ditemukan 62\% mengalami defisiensi seng dan 68,5\% defisiensi vitamin A. Didapatkan hubungan yang bermakna antara defisiensi seng dan vitamin $A(R R=5,833 ; K I ~ 95 \%: 2,816-12,085)$. Selama 6 bulan didapatkan $62 \%$ subjek menderita ISPA dan 30,4\% menderita diare. Terdapat hubungan yang bermakna kejadian ISPA dengan anak defisiensi seng dan atau vitamin $A(R R=2,455 ; K I ~ 95 \%: 1,403-4,297)$. Ditemukan juga hubungan yang bermakna pada kejadian diare dengan anak defisiensi seng dan atau vitamin $A$ (RR=5,984;KI 95\%:1,522-23,534).

Kesimpulan. Status seng dan vitamin A merupakan faktor yang mempengaruhi kejadian ISPA dan diare pada anak. Sari Pediatri 2010;12(4):241-6.
\end{abstract}

Kata kunci: seng, vitamin A, ISPA, diare, anak

\footnotetext{
Alamat korespondensi:

Dr. HM. Nazir Hz, Sp.A(K). Divisi Nutrisi dan Penyakit Metabolik, Departemen Ilmu Kesehatan Anak FK UNSRI-RSMH, Jl Jend. Sudirman km 3,5, Palembang. Telepon (0711) 376445, Fax. (0711) 37644 , E-mail: mnazir12000@yahoo.co.id
}

I nfeksi saluran pernapasan akut (ISPA) dan diare masih merupakan penyebab utama dari morbiditas dan mortalitas anak di negara yang sedang berkembang, termasuk di Indonesia. ${ }^{1,2}$ Kejadian ISPA pada balita diperkirakan 3-6 kali per tahun. ${ }^{2}$ Angka kesakitan diare berkisar 200 sampai 400 kejadian per 1000 penduduk setiap tahun, dan 60\%$80 \%$ kasus adalah golongan usia di bawah lima tahun. ${ }^{1}$ 
Berbagai upaya telah dilakukan pemerintah untuk menurunkan angka kesakitan dan kematian akibat ISPA dan diare. Beberapa penelitian menyatakan pemberian seng selain berperan dalam sistim imun nonspesifik dan spesifik, juga berperan penting dalam metabolisme dan transport vitamin A. Seng berperan dalam sintesis retinol binding protein (RBP). Jika terjadi defisiensi seng maka akan menimbulkan gangguan dalam proses sintesis RBP, sehingga vitamin $A$ akan banyak dalam hati dan rendah dalam sirkulasi darah, berakibat vitamin A tidak dapat berfungsi secara optimal. ${ }^{3} \mathrm{Hal}$ ini akan berpengaruh dalam sistim imun yang menyebabkan anak akan mudah menderita ISPA dan diare. ${ }^{4,5}$ Penelitian Long dkk di Mexico tahun 2006, mendapatkan adanya peningkatan kejadian ISPA (23\%) dan diare (27\%) pada anak yang menderita defisiensi seng dan vitamin A. ${ }^{6}$

Data mengenai interaksi antara seng dan vitamin A pada manusia masih terbatas, oleh karena itu, kami ingin mengetahui bagaimana hubungan antara status seng terhadap kejadian ISPA dan diare pada anak yang secara rutin mendapat vitamin A sesuai program pemerintah, sehingga hasilnya diharapkan dapat menjadi masukan dalam rangka menurunkan angka kejadian ISPA dan diare.

\section{Metode}

Penelitian kohort selama 6 bulan dilaksanakan di lima Posyandu di wilayah kerja Puskesmas Talang Ratu, Palembang, dari minggu ketiga bulan Februari 2009 sampai minggu ketiga bulan Agustus 2009. Subjek penelitian adalah semua anak umur 12-60 bulan yang berkunjung ke posyandu dan orang tua menyetujui untuk ikut dalam penelitian. Subjek diambil secara consequtive sampling. Pada subjek dilakukan anamnesis dan pemeriksaan kadar seng dan vitamin A. Selanjutnya seluruh subjek mendapat vitamin A sesuai dengan program pemerintah. Data kejadian ISPA dan diare pada subjek dicatat dalam lembar kuesioner yang diberikan kepada orang tua subjek dan diberikan kembali ke kader Posyandu setiap bulan selama 6 bulan saat kunjungan ke posyandu.

Subjek didiagnosis menderita defisiensi seng bila kadar seng serum $<70 \mu \mathrm{g} / \mathrm{dl}$, ${ }^{7}$ dan defisiensi vitamin A bila kadar vitamin A serum $<20 \mu \mathrm{g} / \mathrm{dl} .{ }^{8}$ Data diolah dengan program SPSS 15. Data karakteristik subjek dianalisis secara deskriptif dan ditampilkan dalam bentuk tabel distribusi dan frekuensi. Data kategori dianalisis dengan menggunakan chi square sedangkan data numerik dengan uji T. Penelitian sudah disetujui Unit Bioetika FK Universitas Sriwijaya.

\section{Hasil}

Selama periode penelitian, bulan Februari 2009 sampai Agustus 2009 didapatkan 100 subjek penelitian yang memenuhi kriteria inklusi. Terdapat 8 anak yang dikeluarkan dari penelitian, karena tidak melanjutkan ikut dalam penelitian. Karakteristik subjek penelitian tertera pada Tabel 1, didapatkan 70,7\% berumur 1236 bulan dan 53,3\% berjenis kelamin laki-laki, dan $56,5 \%$ subjek mempunyai gizi kurang. Didapatkan juga 93,5\% subjek dengan berat badan lahir normal, dan 79,3\% mendapat ASI ekslusif. Status imunisasi menunjukkan $76,1 \%$ subjek mempunyai status imunisasi lengkap. Karakteristik orang tua subjek penelitian menunjukkan 63\% pendidikan ayah SMA dan 59,85 pendidikan ibu D3. Data pekerjaan ayah subjek terbanyak adalah swasta $(55,4 \%)$.

Tabel 2 menunjukkan hasil pemeriksaan status seng dan vitamin A pada saat awal penelitian. Didapatkan $62 \%$ subjek penelitian menderita defisiensi seng dan $68,5 \%$ defisiensi vitamin A .

Tabel 1. Karakteristik subjek penelitian $(n=92)$

\begin{tabular}{lcc}
\hline Karakteristik & Jumlah & Persentase \\
\hline Umur (bulan) & & \\
12-36 & 65 & 70,7 \\
37-60 & 27 & 29,3 \\
Jenis kelamin & & \\
$\quad$ Laki-laki & 49 & 53,3 \\
$\quad$ Perempuan & 43 & 46,7 \\
Status gizi & & \\
Baik & 40 & 43,5 \\
Kurang & 52 & 56,5 \\
Buruk & - & - \\
Berat lahir (gram) & & \\
$\quad$ Normal ( $\geq 2500)$ & 86 & 93,5 \\
BBLR (<2500) & 6 & 6,5 \\
Riwayat ASI eksklusif & & \\
$\quad$ Ya & 73 & 79,3 \\
$\quad$ Tidak & 19 & 20,7 \\
Riwayat imunisasi & & \\
Lengkap & 70 & 76,1 \\
Tidak lengkap & 22 & 23,9 \\
\hline
\end{tabular}


Tabel 2. Status seng dan vitamin A pada subjek penelitian $(\mathrm{n}=92)$

\begin{tabular}{lcc}
\hline Status & $\mathrm{n}$ & $\%$ \\
\hline Seng $(\mathrm{Zn})$ & & \\
$\quad$ Defisiensi $(<70 \mu \mathrm{g} / \mathrm{dl})$ & 57 & 62,0 \\
Normal $(\geq 70 \mu \mathrm{g} / \mathrm{dl})$ & 35 & 38,0 \\
Vitamin A & & \\
Defisiensi $(<20 \mu \mathrm{g} / \mathrm{dl})$ & 63 & 68,5 \\
$\quad$ Normal $(\geq 20 \mu \mathrm{g} / \mathrm{dl})$ & 29 & 31,5 \\
\hline
\end{tabular}

Hubungan antara status seng dengan vitamin A tertera pada Tabel 3. Terdapat hubungan yang bermakna antara status seng dengan vitamin $\mathrm{A}$ $(\mathrm{p}=0,000)$ dengan nilai RR sebesar 5,833. Data dalam Tabel 3 juga memperlihatkan kuatnya hubungan status seng dan vitamin $A$, terlihat bahwa tidak dijumpai status vitamin A yang normal pada subjek penelitian dengan defisiensi seng.

Kejadian ISPA pada subjek penelitian selama 6 bulan dialami oleh $62 \%$ subjek. Hubungan antara subjek penelitian yang mengalami defisiensi seng dan vitamin A dengan yang normal terhadap kejadian ISPA tertera pada Tabel 4 . Selama 6 bulan pengamatan didapatkan kejadian ISPA pada 50\% subjek penelitian dengan defisiensi seng dan vitamin A dibandingkan hanya 9,8\% bila tidak mengalami defisiensi.

Kejadian diare pada anak selama 6 bulan 30,4\% subjek. Hubungan antara subjek penelitian yang mengalami defisiensi seng dan vitamin A dengan yang tidak defisiensi terhadap kejadian diare tertera pada Tabel 5. Selama pengamatan didapatkan diare pada $28,2 \%$ subjek penelitian dengan defisiensi seng dan vitamin $\mathrm{A}$ dibandingkan hanya 2,2\% dengan kadar normal.

Berdasarkan analisis statistik uji kai kuadrat, terdapat hubungan yang bermakna antara kejadian ISPA pada anak yang tidak mengalami defisiensi seng dan vitamin A dan pada anak dengan defisiensi seng dan atau vitamin $A(p=0,000)$. Nilai risiko relatif $(R R)$ 2,455 dengan $95 \%$ confindence interval diantara $1,403-$ 4,297 (Tabel 6).

Tabel 3. Hubungan status seng dengan vitamin $A(n=92)$

\begin{tabular}{lccccc}
\hline \multirow{2}{*}{ Status seng } & \multicolumn{3}{c}{ Status vitamin A } & RR \\
\cline { 2 - 5 } & $\begin{array}{c}\text { Defisiensi } \\
(<20 \mu \mathrm{g} / \mathrm{dl})\end{array}$ & $\%$ & $\begin{array}{c}\text { Normal } \\
(\geq 20 \mu \mathrm{g} / \mathrm{dl})\end{array}$ & $\%$ & 0 \\
\hline Defisiensi $(<70 \mu \mathrm{g} / \mathrm{dl})$ & 57 & 100,0 & 0 & 5,833 \\
Normal $(\geq 70 \mu \mathrm{g} / \mathrm{dl})$ & 6 & 17,1 & 29 & 82,9 & 0 \\
\hline
\end{tabular}

Uji Fischers , p=0,000, 95\% CI (2,816 -12,085)

Tabel 4. Status seng dan vitamin A dengan kejadian ISPA

\begin{tabular}{|c|c|c|c|c|c|c|}
\hline \multirow{3}{*}{$\begin{array}{l}\text { Status seng dan vitamin A } \\
\qquad \mathrm{n}=92\end{array}$} & \multicolumn{4}{|c|}{ ISPA } & \multirow{2}{*}{\multicolumn{2}{|c|}{ Jumlah }} \\
\hline & \multicolumn{2}{|c|}{ ISPA } & \multicolumn{2}{|c|}{ Tidak ISPA } & & \\
\hline & $\mathrm{n}$ & $\%$ & $\mathrm{n}$ & $\%$ & $\mathrm{n}$ & $\%$ \\
\hline Normal seng dan vitamin $\mathrm{A}$ & 9 & 9,8 & 20 & 21,7 & 29 & 31,5 \\
\hline Normal seng dan defisiensi vitamin A & 2 & 2,2 & 4 & 4,3 & 6 & 6,5 \\
\hline Defisiensi seng dan normal vitamin A & - & - & - & - & - & - \\
\hline Defisiensi seng dan vitamin A & 46 & 50,0 & 11 & 12,0 & 57 & 62,0 \\
\hline Jumlah & 57 & 62,0 & 35 & 38,0 & 92 & 100,0 \\
\hline
\end{tabular}

Tabel 5. Status seng dan vitamin A dengan kejadian diare pada anak

\begin{tabular}{lcccccc}
\hline \multirow{2}{*}{$\begin{array}{l}\text { Status seng dan vitamin A } \\
\mathrm{n}=92\end{array}$} & \multicolumn{3}{c}{ Diare } & \multicolumn{2}{c}{ Jumlah } \\
\cline { 2 - 6 } & $\mathrm{n}$ & $\%$ & $\mathrm{n}$ & $\%$ & $\mathrm{n}$ & $\%$ \\
\hline Normal seng dan vitamin A & 2 & 2,2 & 27 & 29,3 & 29 & 31,5 \\
Normal seng dan defisiensi vitamin A & 0 & 0,0 & 6 & 6,5 & 6 & 6,5 \\
Defisiensi seng dan normal vitamin A & - & - & - & - & - & - \\
Defisiensi seng dan defisiensi vitamin A & 26 & 28,2 & 31 & 33,8 & 57 & 62,0 \\
\hline Jumlah & 28 & 30,4 & 64 & 69,6 & 92 & 100,0 \\
\hline
\end{tabular}

Sari Pediatri, Vol. 12, No. 4, Desember 2010 
Berdasarkan analisis statistik uji Fisher's, terdapat hubungan yang bermakna kejadian diare pada anak yang tidak mengalami defisiensi seng dan vitamin A dan pada anak dengan defisiensi seng dan atau vitamin A ( $\mathrm{p}=0,001)$. Nilai Risk Ratio (RR) sebesar 5,984 dengan 95\% confindence interval di antara 1,522-23,534 (Tabel 7).
Hasil penelitian kami ini sama dengan penelitian di Bangladesh tahun 1995 yang menunjukkan bahwa $>60 \%$ anak masih mengalami defisiensi vitamin A meskipun sudah mendapatkan suplementasi vitamin A dosis tinggi. ${ }^{12}$

Seng mempengaruhi metabolisme vitamin A karena seng dibutuhkan pada sintesis protein transpor

Tabel 6. Risiko anak yang mengalami defisiensi seng dan vitamin A terhadap kejadian ISPA

\begin{tabular}{lccccc}
\hline \multirow{2}{*}{ Status (n=92) } & \multicolumn{4}{c}{ ISPA } & \multirow{2}{*}{ RR } \\
\cline { 2 - 5 } & Ya & $\%$ & Tidak & $\%$ & \\
\hline Defisiensi seng dan atau vitamin A & 48 & 76,2 & 15 & 23,8 & \multirow{2}{*}{2,455} \\
Normal seng dan vitamin A & 9 & 31,0 & 20 & 69,0 & \\
\hline
\end{tabular}

Uji kai kuadrat , p=0,000; 95\% CI (1,403 -4,297)

Tabel 7. Risiko anak yang mengalami defisiensi seng dan vitamin A terhadap kejadian diare

\begin{tabular}{lccccc}
\hline \multirow{2}{*}{ Status ( $\mathrm{n}=92)$} & \multicolumn{3}{c}{ Diare } & \multirow{2}{*}{ RR } \\
\cline { 2 - 4 } & Ya & $\%$ & Tidak & $\%$ & \\
\hline Defisiensi seng dan atau vitamin A & 26 & 41,3 & 37 & 58,7 & 5,984 \\
Normal seng dan vitamin A & 2 & 6,9 & 27 & 93,1 & \\
\hline
\end{tabular}

Uji Fisher's , p=0,001; 95\% CI (1,522 -23,534)

\section{Pembahasan}

Selama periode penelitian didapatkan 92 subjek yang mengikuti penelitian sampai selesai. Rerata umur subjek penelitian adalah $2,39 \pm 1,01$ tahun dan yang menderita defisiensi seng 62,0\%. Penelitian Atmaja $\mathrm{dkk}^{9}$ tahun 1988 pada masyarakat RW. 04 Manggarai Jakarta, mendapatkan 87,99\% anak menderita defisiensi seng, dan penelitian Sayogo tahun 1991 di Kelurahan Utan Kayu Utara, mendapatkan 90,2\%. ${ }^{10}$ Perbedaan ini diduga karena tingginya tingkat pendidikan sebagian besar orang tua subjek dan pekerjaan orang tua yang sebagian besar adalah pegawai swasta yang diyakini pendapatannya dapat mencukupi kebutuhan nutrisi bagi keluarganya.

Kadar vitamin A serum tidak hanya dipengaruhi oleh asupan yang banyak mengandung vitamin A, tetapi juga berhubungan dengan mikronutrien lain yang berperan dalam metabolisme dan transport vitamin A. ${ }^{5}$ Dari penelitian kami menunjukkan meskipun anak sudah mendapat vitamin A dosis tinggi setiap 6 bulan, ternyata prevalensi defisiensi vitamin A masih tinggi (68,5\%). Sejalan dengan Survei Nasional Xeroptalmia tahun 1978 yang mendapatkan 50,2\% anak balita dengan kadar serum vitamin $\mathrm{A}<20 \mathrm{~g} / \mathrm{dl} .{ }^{11}$ retinol (RBP). Selain itu seng juga dibutuhkan pada proses oksidatif vitamin A di jaringan perifer yang membutuhkan aktifasi dari zinc-dependent retinol dehydrogenase enzyme seperti enzim alkohol dehidrogenase $(\mathrm{ADH})$ dan retinal oksidase. Akibat kadar seng yang rendah menyebabkan gangguan dalam proses metabolisme vitamin A, sehingga secara teoritis akan menyebabkan defisiensi vitamin A pada anak yang menderita defisiensi seng. ${ }^{4}$ Hasil penelitian kami menunjukkan hubungan antara kejadian ISPA dan diare antara kadar seng dan vitamin A dengan tidak didapatkannya anak yang mengalami defisiensi seng yang kadar vitamin A normal. Kejadian tersebut memperkuat penelitian yang telah dilakukan Rahman dkk $^{3}$ di Bangladesh tahun 2002 yang menunjukkan bahwa kombinasi suplementasi seng dan vitamin A dapat memperbaiki status vitamin A pada anak.

Kadar seng rendah akan berpengaruh pada fungsi seng sebagai salah satu faktor yang mempengaruhi imunitas tubuh. Seng diperlukan dalam aktifitas biologis tymulin, yaitu suatu hormon nonpeptida yang disekresi oleh sel-sel epitelia tymus yang berguna untuk pematangan limfosit $\mathrm{T}$ dan produksi interleukin-2. Aktifitas tymulin baik invitro maupun invivo sangat dipengaruhi konsentrasi seng dalam serum. Defisiensi 
seng mengakibatkan terjadinya kerusakan epitel saluran nafas, mengganggu fungsi leukosit PMN, sel natural killer, dan aktivasi komplemen, sehingga memudahkan anak menderita ISPA. Defisiensi seng juga menyebabkan rendahnya kadar vitamin A yang menyebabkan terganggunya peran vitamin A dalam sistem kekebalan tubuh untuk deferensiasi limfosit $T$ dan limfosit B, penghambatan apoptosis, serta mempertahankan integritas dan fungsi permukaan mukosa. ${ }^{13}$ Jika terjadi defisiensi vitamin A akan menyebabkan lapisan sel yang menutupi trakea dan paru mengalami keratinisasi, berkurangnya sel goblet, dan sel silia, serta produksi mukus sehingga mikroorganisme mudah masuk ke dalam saluran nafas dan menyebabkan ISPA. ${ }^{14,15}$ Didapatkan $76,2 \%$ anak yang menderita defisiensi seng dan atau vitamin A mengalami ISPA. Kelompok tersebut berisiko dua kali lebih besar untuk mendapatkan penyakit ISPA dibandingkan dengan seseorang yang tidak mengalami defisiensi seng dan vitamin A. Hasil penelitian kami ini sejalan dengan penelitian Long $\mathrm{dkk}^{6}$ di Mexico tahun 2006, yang mendapatkan penurunan kejadian ISPA dan diare pada anak yang mendapatkan suplemen seng dan vitamin A. Bhandari dkk, ${ }^{16}$ juga melaporkan pemberian suplementasi seng pada anak prasekolah di Dakshinpuri New Delhi mengurangi kejadian pneumonia dan ISPA. Hal yang sama dilaporkan oleh Sazawal dkk, ${ }^{17}$ dan Mahalanabis $\mathrm{dkk}^{18}$

Seng berpengaruh baik secara langsung pada sistem gastrointestinal maupun secara tidak langsung dalam sistem imun. Seng berperan dalam menjaga integritas mukosa usus melalui fungsinya dalam regenerasi sel dan stabilitas membran sel. Defisiensi seng merusak epidermis dan mukosa saluran cerna sehingga memudahkan invasi kuman pada saluran cerna. ${ }^{13}$ Vitamin A berperan pada proliferasi dan diferensiasi sel serta sistem imunologi. Bila terjadi defisiensi vitamin A akan menyebabkan anak rentan terhadap penyakit diare. ${ }^{13}$ Dari penelitian kami didapatkan, 41,3\% subjek dengan defisiensi kadar seng dan atau vitamin A yang mengalami diare. Didapatkan juga hubungan kejadian diare pada anak yang mengalami defisiensi seng dan atau vitamin $\mathrm{A}$.

Anak-anak yang mengalami defisiensi vitamin A akan menderita ISPA dan diare lebih tinggi dibandingkan anak normal walaupun sama-sama mendapatkan suplementasi vitamin A. Temuan ini selain bisa disebabkan dosis vitamin A yang diberikan dalam program pemerintah belum mencukupi untuk meningkatkan kadar vitamin A (terutama anak-anak dengan kadar yang sangat rendah) menjadi normal, juga bisa disebabkan adanya faktor lain yang berhubungan dengan metabolisme vitamin A, seperti rendahnya kadar seng. Hasil penelitian kami menunjukkan peran seng yang sangat penting dalam metabolisme vitamin A. Diperlukan penelitian lanjutan untuk mengetahui kadar vitamin A pada anak yang mendapat suplementasi seng sebelum diberikan vitamin A sesuai program pemerintah. Tabel 3 menunjukkan bahwa tidak ada subjek yang memiliki kadar vitamin A normal bila mengalami defisiensi seng. Selain itu juga didapatkan anak dengan defisiensi seng akan berpeluang lebih besar menderita ISPA dan diare dibandingkan dengan anak anak defisiensi vitamin A.

Disimpulkan seng dan vitamin A merupakan salah satu faktor yang berpengaruh terhadap kejadian ISPA dan diare pada anak. Seng juga berperan dalam metabolisme vitamin A sehingga mempengaruhi status vitamin $\mathrm{A}$.

\section{Daftar pustaka}

1. Soeparto P. Sumbangan dan peran kaum professional dalam mendukung program penyakit saluran cerna di era otonomi. Dalam :Kumpulan makalah Kongres Nasional BKGAI II Medan: BKGAI;2003.h.17-27.

2. Wantania JM, Naning R, Wahani A. Infeksi respiratori akut. Dalam: Rahajoe NN, Supriyatno B, Setyanto DB, penyunting. Buku Ajar Respirologi. Edisi 1. Badan Penerbit IDAI;2008.h.268-77.

3. Rahman MM, Wahed MA, Fuchs GJ, Baqui AH, Alvarez JO. Synergistic effect of seng and vitamin $A$ on the biochemical indexes of vitamin A nutrition in children. Am J Clin Nutr 2002;75:92-8.

4. Christian P, Keith PW Jr. Interaction between zinc and vitamin A: an update. Am J Clin Nutr1998; (68suppl):435s41 s.

5. Sommer A, Katz J, Tarwotjo I. Increased risk of respiratory disease and diarrhea in children with preexizting mild vitamin A deficiency. Am J Clin Nutr 1984;40:1090-95.

6. Long KZ, Montoya Y, Hertzmark E, Santos JI, Rosado JL. A double-blind, randomized, clinical trial of the effect of vitamin A and zinc supplementation on diarrheal disease and respiratory track infection in children in Mexico City, Mexico. Am J Clin Nutr 2006;83:693700.

7. Prasad AS. Zinc deficiency in women, infants and 
children. J Am Coll Nutr 1996; 15:113-20.

8. Boron B, Hupert J, Barch DH. Effects of zinc deficiency on hepatic enzymes regulating vitamin A status. J Nutr 1988;118:995-1000.

9. Atmaja DS, Japaris W, Suswanto E. Penelitian Status Seng dengan test kecap Smith pada masyarakat RW 04 Manggarai Jakarta; M Ked Ind 1988;38:611-6.

10. Sayogo S. Defisiensi seng pada anak usia 12-15 tahun di kelurahan Utankayu Utara. M Ked Ind 1991;20:34-8.

11. Kerangka Acuan Persiapan Survei Kurang Vitamin A, Anemia, dan Seng (Zn). Puslitbang Gizi. DepKes RI. Didapat dari: http://www.gizinet.com.

12. Mahalanabis D, Rahman MM, Wahed MA, Islam MA, Habte D. Vitamin A megadose during early infancy on serum retinol concentration and acute side effects and residual effect on 6 month follow-up. Nutr Res 1997;17:649-59.

13. Shankar AH, Prasad AS. Zinc and immune function: the biological basis of altered resistance to infection. Am J
Clin Nutr 1998;68(suppl):447s-63s.

14. Semba RD. Vitamin A and immunity to viral, bacterial and protozoan infections. Proceedings of the Nutrition Society 1999;58:719-27.

15. Semba RD. Vitamin A as "anti-infective" therapy. J Nutr1999;129:783-91.

16. Bhandari N, Bahl R, Taneja S. Effect of routine zinc supplementation on pneumonia in children aged 6 months to 3 years: randomised controlled trial in an urban slum. BMJ 2002;324:1358

17. Sazawal S, Black RE, Jalla S, Mazumdar S. Zinc supplementation reduces the insidence of acute lower respiratory infections in infants and preschool children: a double blind controlled trial.Pediatrics 1998;102:1-5.

18. Malahanabis D, Lahiri M, Paul D. Randomized, double blind, placebo- controller clinical trial of the effocacy of treatment with zinc or vitamin A in infants and young children with severe acute lower respiratory infection. Am J Clin 2004;79:430-6. 